\title{
Barley green fodder production and effect of different saline water levels under hydroponic condition
}

\author{
Basel Natsheh \\ Department of Environment and Sustainable Agriculture, Faculty of Agriculture science and technology, \\ Palestine Technical University - Kadoorie, Tulkarm, Palestine.
}

\begin{abstract}
The objective of this study to evaluate the effect of different saline water levels on barley (Hordeum vulgare) growth for green fodder production under hydroponic condition. The experiment has been conducted under temperature-controlled conditions $\left(24 \pm 1{ }^{\circ} \mathrm{C}\right)$ and natural window illumination at growth room of Soilless Culture in the Laboratory, Kadoorie Agricultural research center, Palestine Technical University (Kadoorie), Tulkarm, Palestine. Cultivation of tested seed started at 12- April - 2017. The experimental work included 2 trails, first one intended to evaluate germination percentage by using three Petri-dish, 100 seeds planted, the average seeds germination was $95 \%$. The other trial contain four treatments (tap water, 3, 6 and $9 \mathrm{ds} / \mathrm{m}$ ) carried out under room conditions to evaluate the (shoot $\&$ root) length and weight, all data recorded daily to determine the effect of different saline water levels on barley green fodder production. The results showed that green fodder can be production during 8-10 days from planting to harvest. The results showed the barley plant wet weight gave a good values when used (3, 6 and $9 \mathrm{ds} / \mathrm{m})$ saline water levels (1957, 2096 and $2117 \mathrm{gm}$ ) respectively, better than tap water $1746 \mathrm{gm}$, while the results for barley plant length gave a maximum values when used $(3$ and $6 \mathrm{ds} / \mathrm{m})$ saline water levels $(20$ and $19 \mathrm{~cm})$, respectively, better than used tap water and $9 \mathrm{ds} / \mathrm{m}(15$ and $16 \mathrm{~cm})$, respectively. There is inverse relation between root and salt concentration, decreasing the root length when used $9 \mathrm{ds} / \mathrm{m}$ water saline level $(1 \mathrm{~cm})$ in comparison the other treatments are due to increasing the salt concentration.
\end{abstract}

Keywords: Barley, Hydroponic, salinity water, germination percentage, green fodder.

\section{Introduction}

Shortage agricultural water use while maintaining or improving economic productivity of the agricultural sector is a major challenge in arid and semiarid regions. Irrigated agriculture is the major consumer of fresh water supplies in many parts of the world, particularly in relatively arid and semiarid regions like Palestine, Jordan as well as Gulf Cooperation Council countries (GCC). The demand on scarce water resources in these countries is increasing with time for both agricultural and non-agricultural purposes. Over recent years, severe shortages in food supplies for livestock have been experienced in Palestine, Jordan and GCC countries as well as many other countries.

In the region, mainly, due to repeated droughts as well as shortages of water for irrigation. Many projects to produce forages have been established during the last two decades to cover some green and dry forage needs in these countries. However, scarcity of adequate fresh water supplies might pose challenges for sustainability of the field projects especially with utilizing ground water for irrigation, which is consumed in large amounts as these countries are characterized with very high rates of evapotranspiration and soils of low capacity to retain water. Therefore, methods and technologies that can contribute to improved water use efficiency and productivity merit closer consideration like hydroponic technique.

Hydroponic technique can be used for green fodder production of many forage crops in a hygienic environment free of chemicals like insecticides, herbicides, fungicides, and artificial growth promoters[1-3]. It is a wellknown technique for high fodder yield, year round production and least water consumption [3-6]. 
Unlike field production system that use run-to-waste irrigation practices, the hydroponic fodder system uses recirculation system, thus reducing the waste water. It has been reported that hydroponic fodder production requires only about $2-3 \%$ of that water used under field conditions to produce the same amount of fodder[3]. Fodder produced hydroponically is of a short growth period 8-10 days and does not require high- quality arable, but only a small piece of land for production to take place [5, 7]. It is of a high feed quality, rich with proteins, fiber, vitamins, and minerals[8-10]. All these special features of hydroponic system, in addition to others make it one of the most important agricultural techniques currently in use for green forage production in many countries especially in arid and semi-arid regions of the world. However, determining the best forage crop is an important matter in producing highest fodder yield and quality and at the same time considering the economic dimensions in the process of hydroponic green fodder production by saving of seeds costs.

The objective of this study were to evaluate the effect of different saline water levels on barley Hordeum vulgare growth for green fodder production and saline water use efficiency under hydroponic cultivation condition.

\section{Materials and Methods}

The experiment has been conducted under temperature-controlled conditions $\left(24 \pm 1^{\circ} \mathrm{C}\right)$ and natural window illumination at growth room of Soilless Culture in the Laboratory Kadoorie Agricultural research center, Palestine Technical University (Kadoorie), Tulkarm, Palestine. ,cultivation of tested seed started at 12- April 2017. The experimental work included 2 trail, first trail conducted for germination percentage test, using three Petri-dish's, 100 seeds planted for each, the average seeds that germinated $95 \%$. the other trial were four treatments (F.w, 3, 6 and $9 \mathrm{ds} / \mathrm{m}$ ) carried under laboratory conditions to evaluate the shoot and root length and weight were all data recorded for used to determine the effect of saline water on green fodder production.

2.1. The Hydroponic System: The hydroponic system included 4 treatments, a plastic tray, each tray have length $75 \mathrm{~cm}$, a width $17.5 \mathrm{~cm}$, a height $2.5 \mathrm{~cm}$ and weight $233 \mathrm{gm}$ as bellow in figure 1 . Each treatment contain 3 trays with capacity to produce maximum productivity, depending on barley variety, and growth conditions [3]. The relative humidity in the growth room ranged between 60 and $70 \%$.

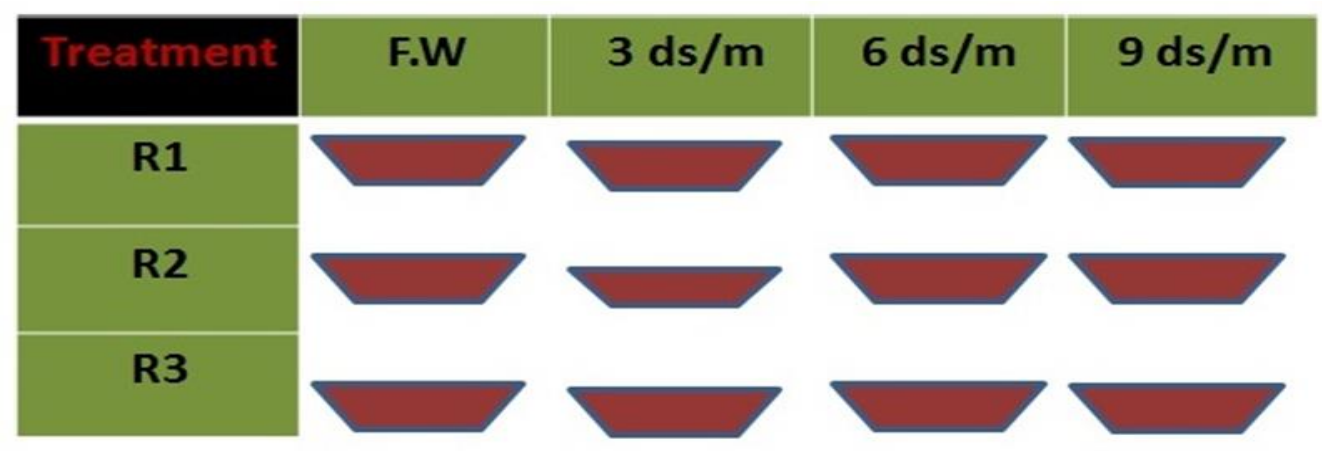

Figure 1. Layout of the experiment units used in hydroponic green fodder barley production

2.2. Barley Plant (Hordeum vulgare): as a local crop in Palestine, evaluated in this study, the seeds of crop obtained from the local market of Tulkarm, Palestine. Seeds of barley crop were subjected to a germination test to check for their viability before being used; the results of the germination test $92 \%$ for barley.

2.3. Seeds treatment before Planting: barley seeds cleaned from debris and other foreign materials, cleaned seeds sterilized by soaking 30 minutes in a $20 \%$ sodium hypochlorite solution (household bleach) to control the formation of mold. Planting trays also cleaned and disinfected. The seeds washed well from residues of bleach and re-soaked in tap water overnight (about 12 hours) before planting. 
2.4. Seed Planting and Irrigation: barley seeds put in plastic trays. The seeding rates used in this experiment $0.5 \mathrm{~kg}$ per tray of barley. These rates were based on seeds size and weight to have approximately the same number of plants per tray. Trays were irrigated manually with tap and saline water daily according the treatments. At a fixed rate of $250 \mathrm{ml}$ tray day which was enough to keep the seeds/seedlings moist.

2.5. Fodder Yield: The experiment terminated after 8-10 days from seeding, the fodder biomass ready for harvest figure 2 .

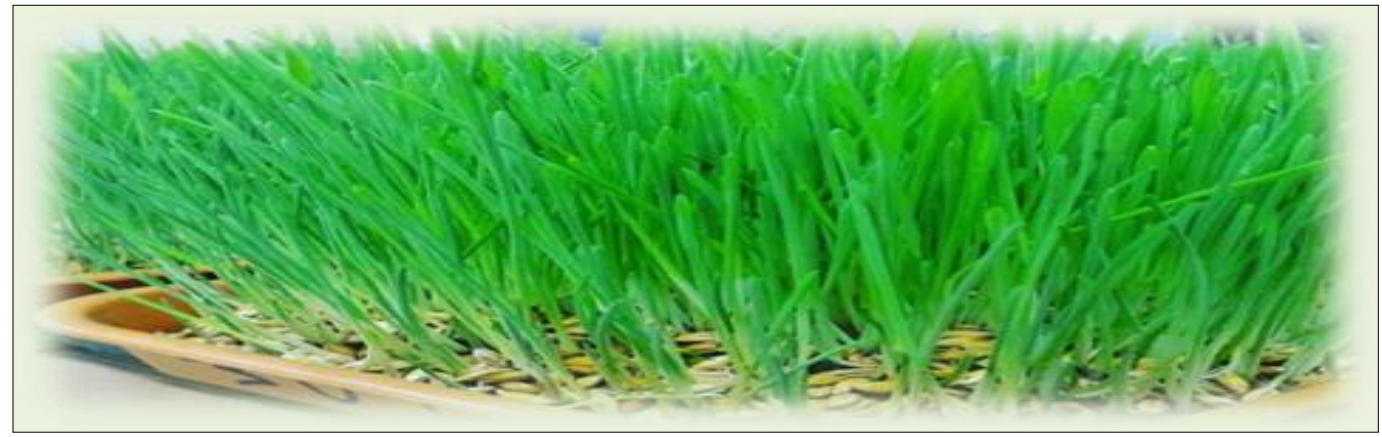

Figure 2. The fodder biomass was ready for harvest after 8-10 days from seeding.

2.6. Total Water Use. Fresh water collected for irrigation from Tulkarm municipal tap water. Saline water was prepared before each irrigation according to this equations:

$\operatorname{TDS}(\mathrm{mg} / \mathrm{L})=\mathrm{EC}(\mathrm{ds} / \mathrm{m}) * 640$ for EC between 0.1 and $5 \mathrm{ds} \backslash \mathrm{m}$.

TDS $(\mathrm{mg} / \mathrm{L})=\mathrm{EC}(\mathrm{ds} / \mathrm{m}) * 800$ for EC greater than $5 \mathrm{ds} \backslash \mathrm{m}$.

28.5 (gram of salt) dissolved in 15 liter of distil water to have saline irrigation water with 3ds/l.

72 (gram of salt) dissolved in 15 liter of distil water to have saline irrigation water with 6ds/l.

108 (gram of salt) dissolved in 15 litter of distil water to have saline irrigation water with 9ds/l.

The total water in the experiment were recorded per tray every day to compute total water use and water use efficiency. The total water used by plants (litters/tray) was computed $250 \mathrm{ml}$ per day.

2.7. Experimental Design and Statistical Analysis. The completely randomized design was used with three replicates. Data were statistically analyzed using analysis of variance (ANOVA) according to the statistical package MSTAT-C (Michigan State University, East Lansing, MI, USA). Probabilities of significance among treatments (crops) and LSD $(\mathrm{P} \leq 0.05)$ were used to compare means among treatments.

\section{Results and Discussion}

The experimental work included 2 groups, first one for germination percentage test using three Petri dishes and irrigated by fresh water (F.W) to calculate the seeds germination percentage. 100 seeds/ Petri dish, the average seeds germinated was $92 \%$. The other group conducted to study the effect of different saline water levels on shoot and root plant length, wet green fodder weight. 12 trays used as experimental units, $0.5 \mathrm{~kg}$ from barley seeds distributed for each tray, were all data recorded daily to determine the green fodder production and compared between the 4 treatments under study (F.W, 3-6-9 ds/m).

Water is one of the basic requirements for seed germination and seedling growth as it is essential for enzyme activation, reserve storage breakdown, translocation, and use in seed germination and seedling growth [11]. Hydroponically produced fodder was found to enhance the efficiency of water use (WUE). reported that 
hydroponic green fodder production technique requires only about $10-20 \%$ of the water needed to produce the same amount of crop in soil culture [12].

\section{Barley plant wet weight}

Hydroponics, the 'water culture' of plants, has been used in research and commercial contexts since the 18th century. Although now used successfully on a large scale by commercial grower of fast-growing horticultural crop such as barley to produce the green fodder, hydroponics was initially developed as a part of early research into plant nutrition.

Barley plant wet weight was one of an important measurement to study the effect of saline water levels on barley production as green fodder, the values below in table 1. Showed and illustrate the data collected during the experimental work to evaluate the effect of saline water level on barley growth behaviour and limited the better productivity between treatments.

Results in barley plant wet weight gave a good values when used (3, 6 and $9 \mathrm{ds} / \mathrm{m})$ saline water levels better than (F.w) or tap water, that means the barley plants is a tolerance for saline water used, in addition the maximum green fodder values was when used 6 and $9 \mathrm{ds} / \mathrm{m}$ in comparison with fresh water and $3 \mathrm{ds} / \mathrm{m}$. Figure 3. Showed clearly the difference between the treatments used in the experiment, the maximum value when used $9 \mathrm{ds} / \mathrm{m}$, reached $2117 \mathrm{gm}$, comparing with Fresh water $1746 \mathrm{gm}$. the results also indicated that the plant wet weight was better with increasing saline water levels used.

Table.1. Illustrated the data collected during the experimental work to evaluate the effect of saline water level on barley wet weight.

\begin{tabular}{lllll}
\hline Plant wet weight & T1 & T2 & T3 & T4 \\
gm & Tap water & 3ds/m & $6 \mathrm{ds} / \mathrm{m}$ & 9ds/m \\
\hline R1 & $1758 \mathrm{c}$ & $1970 \mathrm{~b}$ & $2021 \mathrm{a}$ & $1998 \mathrm{a}$ \\
\hline $\mathrm{R} 2$ & $1740 \mathrm{c}$ & $1996 \mathrm{~b}$ & $2162 \mathrm{a}$ & $2218 \mathrm{a}$ \\
\hline $\mathrm{R} 3$ & $1712 \mathrm{c}$ & $1905 \mathrm{~b}$ & $2106 \mathrm{a}$ & $2135 \mathrm{a}$ \\
\hline Average $(\mathrm{gm})$ & $1746 \mathrm{c}$ & $1957 \mathrm{~b}$ & $2096 \mathrm{a}$ & $2117 \mathrm{a}$ \\
\hline
\end{tabular}

The green fodder yield varies according to type of grain. It was reported by previous research that $1 \mathrm{~kg}$ of barley grains produced a green fodder yield ranging from 7 to $10 \mathrm{~kg}$ [13]-[14] indicating that barley and wheat were the most appropriate. 


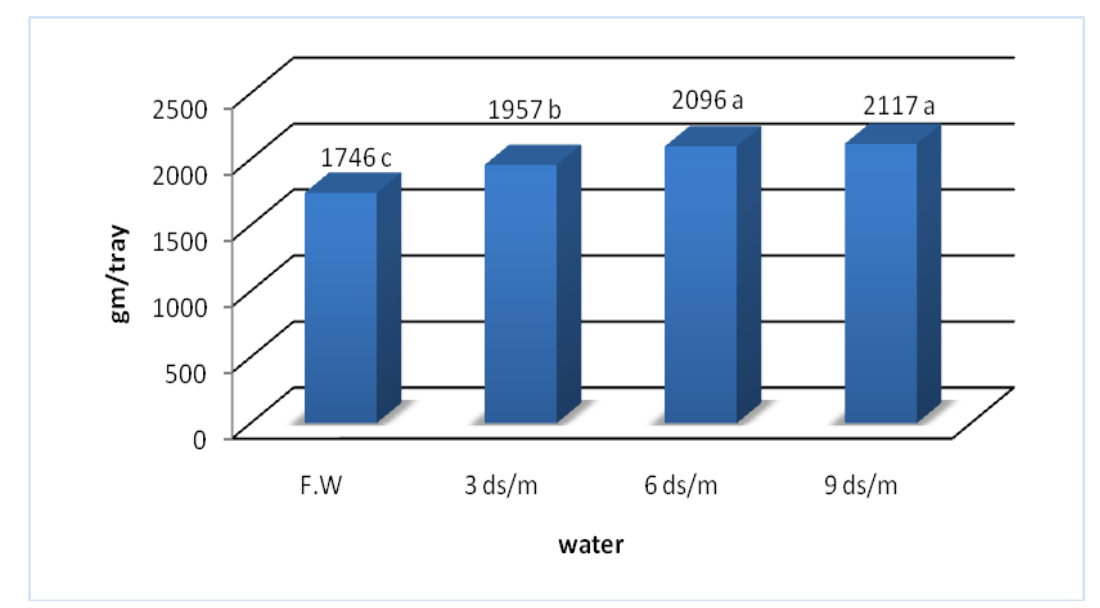

Figure 3. Illustrated the average barley wet weight collected during the experiment work to evaluate the effect of saline water level on barley cultivation.

Different salinity levels had a significant effect on shoot fresh while the effect on shoot dry weight was statistically non significant. Shoot fresh of barley and oat decreased when $\mathrm{NaCl}$ salinity was increased. Maximum shoot fresh weight (4.49 g) was produced from control treatment ( 0 mole m-3 NaCl salinity) while minimum shoot [15].

Fresh weight $(2.20 \mathrm{~g})$ of the same crop was noted in those pots where plant received high level of salinity (150mole m-3). In case of oat, shoot fresh weight was maximum $(5.08 \mathrm{~g})$ when plants were grown in control treatment while minimum shoot fresh weight $(1.90 \mathrm{~g})$ was recorded at 150 mole m-3. Both crop plants grown under non saline condition produced maximum shoot dry weight $(0.86$ and $0.99 \mathrm{~g}$ for barley and oat respectively) while minimum shoot dry weight was observed in case plants of both the crops were exposed to high salt concentration. Similar results are also reported by [16] and [17], they stated that with an increase in salt concentration, shoot and root dry weight, seedlings height and root length decreased.

\section{Plants shoot length in barley}

Barley plant height as the second important measurement to study the effect of saline water levels on barley green fodder production, the values showed bellow in table 2. and figure 4. Illustrated the data collected during the experimental work to evaluate the effect of saline water levels on barley length during the experimental time.

Results in barley plant height gave a good values and indication about the effect of different saline water levels under study, $(3,6$ and $9 \mathrm{ds} / \mathrm{m})$ saline water levels better than used tap water, that means the barley plants has ability to produce green fodder under saline water used, in addition the maximum plant height green fodder values was in 3 and $6 \mathrm{ds} / \mathrm{m}$ in comparison with fresh water and $9 \mathrm{ds} / \mathrm{m}$.

Table 2. Illustrated the data collected during the experimental work to evaluate the effect of saline water level on barley length.

\begin{tabular}{lllll}
\hline $\begin{array}{l}\text { Plant length } \\
\mathrm{cm}\end{array}$ & T1 & T2 & T3 & T4 \\
\hline $\mathrm{R} 1$ & Tap water & $3 \mathrm{ds} / \mathrm{m}$ & $6 \mathrm{ds} / \mathrm{m}$ & $9 \mathrm{ds} / \mathrm{m}$ \\
\hline $\mathrm{R} 2$ & $15 \mathrm{c}$ & $18 \mathrm{~b}$ & $17 \mathrm{~b}$ & $15 \mathrm{c}$ \\
\hline R3 & $16 \mathrm{c}$ & $20 \mathrm{a}$ & $19 \mathrm{a}$ & $16 \mathrm{c}$ \\
\hline Average $(\mathrm{cm})$ & $14 \mathrm{c}$ & $21 \mathrm{a}$ & $20 \mathrm{a}$ & $17 \mathrm{bc}$ \\
\hline
\end{tabular}


Results in barley plant length gave a good values when used ( 3 and $6 \mathrm{ds} / \mathrm{m}$ ) saline water levels better than used (F.w) or tap water, that means the barley plants is tolerance for saline water used, in addition the maximum green fodder length when used 3 and $6 \mathrm{ds} / \mathrm{m}$ in comparison with fresh water. Figure 4. Showed clearly the difference between the treatments used in the experiment and were the maximum value when used 3 and $6 \mathrm{ds} / \mathrm{m}$, reached 20,19 cm, comparing with Fresh water $15 \mathrm{~cm}$, the results also indicated that the plant height was decreasing with increasing saline water levels used but is better than used fresh water or tap water.

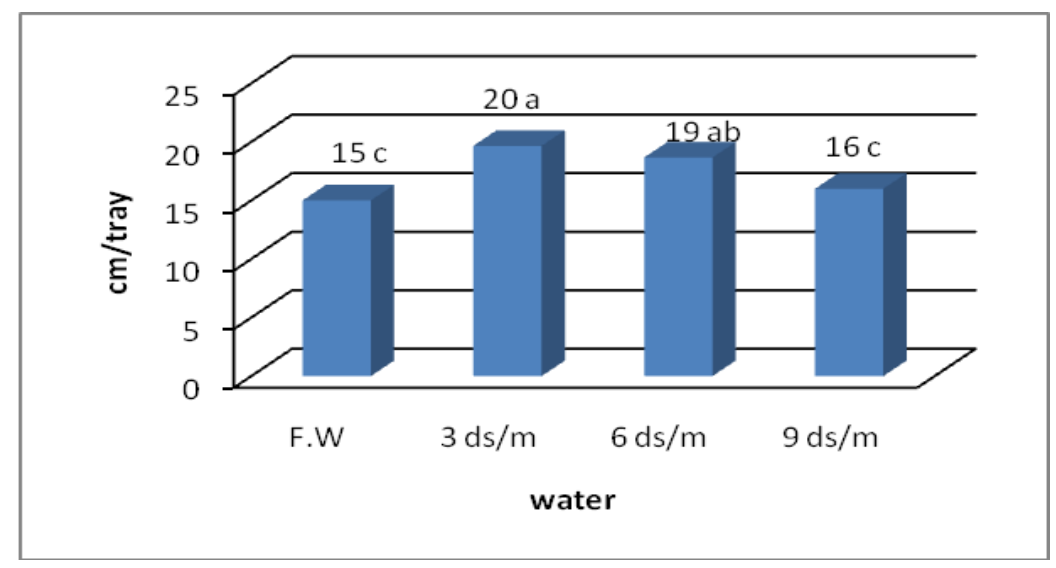

Figure 4. Illustrated the average barley length collected during the experiment work to evaluate the effect of saline water level on barley cultivation.

\section{Plants root length in barley}

The effect of saline water levels on plants root take the same trend with the plant height were the maximum values $(3 \mathrm{~cm}$ ) used 3 and $6 \mathrm{ds} / \mathrm{m}$ saline water levels in comparing with $9 \mathrm{ds} / \mathrm{m}$. Table 3 . and figure 5 . Illustrated decreasing the root length when used $9 \mathrm{ds} / \mathrm{m}$ water saline level are due to increasing the salt concentration, then increases the osmotic pressure in the spread of the root zone and to enable the plant to resist these inappropriate conditions in the soil solution are plant cells lifting of internal osmotic pressure of Sito-blasma and this is what leads to the loss of plant bio-energy necessary for development and growth the root, which leads to weakness and lack of productivity However, seeds subjected to high salinities could germinate when placed under non saline conditions.

Table 3. Illustrated the effect of saline water levels on root length due to increasing the salt concentration.

\begin{tabular}{lllll}
\hline Root length & T1 & T2 & T3 & T4 \\
$\mathrm{cm}$ & Tap water & $3 \mathrm{ds} / \mathrm{m}$ & $6 \mathrm{ds} / \mathrm{m}$ & $9 \mathrm{ds} / \mathrm{m}$ \\
\hline $\mathrm{R} 1$ & $2 \mathrm{~b}$ & $3 \mathrm{a}$ & $3 \mathrm{a}$ & $1 \mathrm{c}$ \\
\hline $\mathrm{R} 2$ & $2 \mathrm{~b}$ & $3 \mathrm{a}$ & $2 \mathrm{~b}$ & $1 \mathrm{c}$ \\
\hline $\mathrm{R} 3$ & $3 \mathrm{a}$ & $3 \mathrm{a}$ & $3 \mathrm{a}$ & $1 \mathrm{c}$ \\
\hline Average $(\mathrm{cm})$ & $2 \mathrm{~b}$ & $3 \mathrm{a}$ & $3 \mathrm{ab}$ & $1 \mathrm{c}$ \\
\hline
\end{tabular}

Root length is one the most important features for salt stress because of contacting with soil directly. As you see by increasing salinity doses, rate of root length decreased extremely. In this case, on control conditions we had the tallest root length with $3.82 \mathrm{~cm}$ and the smallest shoot length was seen $0.10 \mathrm{~cm}$ in $240 \mathrm{mM}$. Comparing control, root length reductions were determined as $12.40,22.33,69.50$ and $96.86 \%$ in 20, 80, 160 and $240 \mathrm{NaCl}$ doses, respectively[19]. 


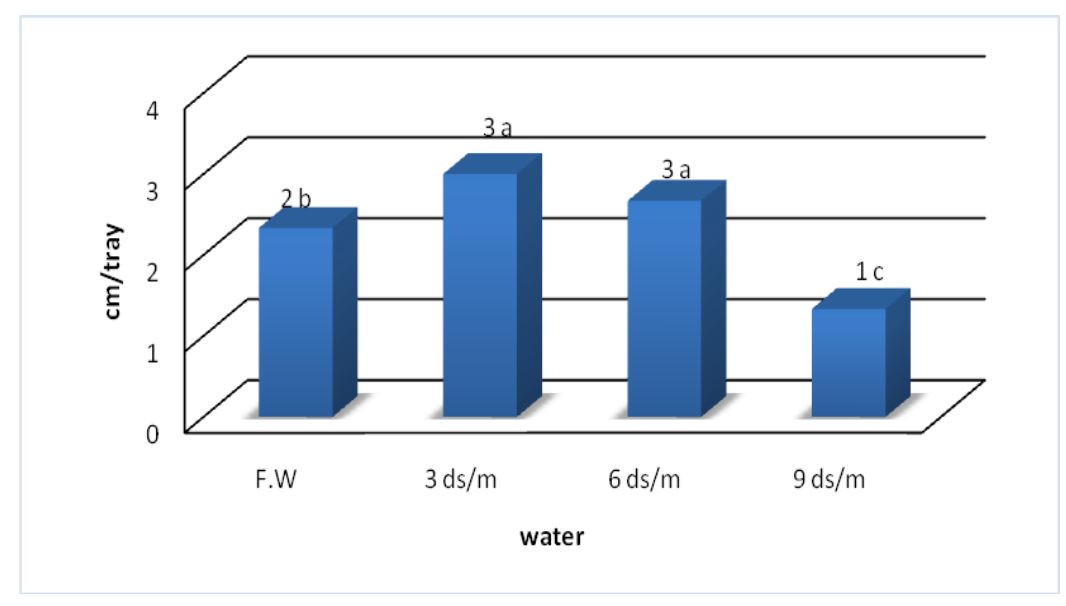

Figure 5. Illustrated the average barley root length collected during the experiment work.

Root fresh and dry weight was significantly affected by different levels of salinity. that increasing salinity had significantly reduced root fresh and dry weight of barley and oat. A negative correlation between root fresh and dry weights and different salinity levels was observed. Root fresh and dry weight in both crops were maximum when plants were grown under control environment while high salt concentration resulted in minimum root fresh and dry weight of both the crops. Similar results are also reported by [16]- [18]they stated that with an increase in salt concentration, shoot and root dry weight, seedlings height and root length decreased.

\section{Conclusions}

After evaluating the data collected from the experiment it is clear that various saline water levels played a role in barley green fodder production. The germination stage being very sensitive to the salinity level, due to this reason all treatments germinated by tap water to reach maximum germination seeds. Using salinity level $9 \mathrm{ds} / \mathrm{m}$ did not stop germination but delayed growth with time.

Barley is appeared a tolerance plants for salinity and gave a green fodder production until if used high salinity level $9 \mathrm{ds} / \mathrm{m}$.

Barley green fodder production weight was maximum when using $(6 \& 9) \mathrm{ds} / \mathrm{m}$ saline water level. The results showed the barley plant wet weight give a good values when used $(3,6$ and $9 \mathrm{ds} / \mathrm{m})$ saline water levels better than used fresh water or tap water, that means the barley plants is tolerance for saline water used, in addition the maximum green fodder values when used 6 and $9 \mathrm{ds} / \mathrm{m}$ in comparison with fresh water and $3 \mathrm{ds} / \mathrm{m}$.

The results indicated the barley plant height gave a good values when used ( 3 and $6 \mathrm{ds} / \mathrm{m}$ ) saline water levels better than used fresh water or tab water, that means the maximum green fodder length were used 3 and $6 \mathrm{ds} / \mathrm{m}$ in comparison with fresh water.

The results showed there is inverse relation between root and salt concentration, were decreasing the root length when used $9 \mathrm{ds} / \mathrm{m}$ water saline level are due to increasing the salt concentration, then increases the osmotic pressure in the spread of the root zone.

Finally the important thing and after calculated each $350 \mathrm{gm}$ from barley seeds gave: $1746 \mathrm{gm}$ using fresh water, 1957 gm using 3ds/m, 2096 gm using 6ds/m and $2117 \mathrm{gm}$ using $9 \mathrm{ds} / \mathrm{m}$.

The use of salt water in agriculture helps us to preserve water resources and provide large quantities of fresh water for human use in light of the current shortage of water and provide it for future generations in an environmentally friendly way. 


\section{Acknowledgements}

Thanks are due to the Prof. Dr. Noor Abo Alrob, President, Palestine Technical University Kadoorie the generous support for scientists and researchers. Thanks for Laboratory of Agricultural Research Center staff, Palestine Technical University (Kadoorie), Tulkarm, Palestine.

\section{References}

[1] M. H. Jensen and A. J.Malter, "Protected agriculture: a global review,"World Bank Technical Paper 253, 1995.

[2] M. M. Al-Hashmi, Hydroponic green fodder production in the Arabian Gulf Region, M.S. thesis, Faculty of Graduate Studies, Arabian Gulf University, Manama, Bahrain, 2008.

[3] G. N. Al-Karaki and N. Al-Momani, "Evaluation of some barley cultivars for green fodder production and water use efficiency under hydroponic conditions," Jordan Journal.

[4] G.Tudor, T. Darcy, P. Smith,andF. Shallcross, "The intake and liveweight change of drought master steers fed hydroponically grown, young sprouted barley fodder (Autograss)," Department of Agriculture Western Australia, 2003.

[5] D. Cuddeford, “Hydroponic grass,” In Practice, vol. 11, no. 5, pp. 211-214, 1989.

[6] G. N. Al-Karaki, "Utilization of treated wastewater for green forage production in a hydroponic system," Emirates Journal of Food and Agriculture, vol. 23, pp. 80-94, 2011.

[7] J. Mooney, “Growing cattle feed hydroponically,” Meat and livestock Australia, 2005.

[8] V. Bhise, J. Chavan, and S. Kadam, "Effects ofmalting on proximate composition and in vitro protein and starch digestibilities of grain sorghum," Journal of Food Science and Technology, vol. 25, no. 6, pp. 327-329, 1988 .

[9] T. Y. Chung, E. N. Nwokolo, and J. S. Sim, "Compositional and digestibility changes in sprouted barley and canola seeds," Plant Foods for Human Nutrition, vol. 39, no. 3, pp. 267-278,1989.

[10] K. Lorenz, "Cereal sprouts: composition, nutritive value, food applications," Critical Reviews in Food Science and Nutrition, vol. 13, no. 4, pp. 353-385, 1980.

[11] O. L. Copeland and M. B. Mcdonald, Seed Science and Technology, Chapman and Hall, New York, NY, USA, 3rd edition, 1995.

[12] P. Bradley and C. Marulanda, "Simplified hydroponics to reduce global hunger," Acta Horticulture, vol. 554, pp. 289-295, 2000.

[13] Mukhopad, Y. (1994) Cultivating Green Forage and Vegetables in the Buryat Republic. MezhdunarodnyiSel'skokhozyaistvennyiZhurnal, 6, 51-52.

[14]Buston, C.D.E., Gonzalez, E.L., Aguilera, B.A. and Esptnoz, G.J.A. (2002) Forrajehidropónicounaalternativa para lasuplementacióncaprinaen el semidesier to Queretano pp: 383. XXXVIII ReuniónNacional de InvestigaciónPecuaria.Puebla, México.

[15] Jehan B., et. Al., 2007. Grouth performance of oat and barley at early seedling stage under saline environment. Sarhad J. Agric. Vol. 23, No. 3.

[16] Rotella, M.A. and V. Martinez. 1997. Effect of salinity on the growth and nitrogen uptake by wheat seedlings. J. Plant Nutr. 20 : 793-804.

[17] Maiti, R.K., A.A.L. Gutierrez and M. De LaRosa Ibara. 1994. Evaluation of several sorghum genotypes for salinity tolerance. Int'l. sorghum and millets News letter. 35: 121.

[18] Day, A.D. and M.R. Elimigri. 1986. Response of barley genotypes to saline and non saline environments. J. Arid Envir. 10: 117-125.

[19] Mahmut ÇAMLICA , Gülsüm YALDIZ. 2017. Effect of Salt Stress on Seed Germination, Shoot and Root Length in Basil (Ocimum basilicum). Int. J. Sec. Metabolite, Vol. 4: 3 (2017) pp. 69-76. 